\title{
Policing - the technological revolution: Opportunities \& Challenges!
}

\author{
By \\ Sarah Jane Fox ${ }^{1}$
}

\section{Introduction}

Policing in the UK remains a constantly challenging role to undertake; but, nevertheless it remains essential to maintaining law, peace and order. Whilst retaining the original intention for the function of a police officer, there is little doubt that the role of a constable has had to adapt to societies' changes and part of this has necessitated the implementations of systems and technologies to make the police more efficient and effective. Nevertheless, at times, achieving equilibrium between what the public want and even 'demand' of their police and what is feasible and realistic has been a difficult act to balance. This includes with regards to the utilisation of technology used in a policing role. This has no doubt also been influenced by the past in terms of trust and accountability; and, society striving to hold onto past models of policing that had at the heart the community 'Bobby'.' This model arguably additionally strips the officer of his/her technology - and at time, physical mobility in terms of motorised vehicles and the equipment contained within.

The police are viewed as a central element within a democratic society, being arguably "the central public service in a modem state" (Jones et al, 1994). The fundamental basis of

\footnotetext{
${ }^{1}$ The author would like to thank Essex Police for their contributions with regards to the drone study within the latter section. Inspector Aaron Connolly is cited for contributing to this section (Section: 5.1.1.).

2 The nickname 'Bobby' comes from Sir Robert Peel, who founded the Met with an Act of Parliament in 1829 policeman were also first known as 'peelers' in his honour.
} 
Accepted 10 September 2018 (Journal - Technology in Society)

Accepted manuscript available online: 21-SEP-2018

https://doi.org/10.1016/j.techsoc.2018.09.006

policing, in the UK, has always been recognised to be firmly established as embodying the concept of policing by consent which entails the support of the communities that are served.

However, there is much debate as to the contemporary understandings of democracy which is said to continually, "preoccupy the academic landscape, ... across the globe" (Cavanaugh and Hughes, 2016). This has led to radical thoughts being expressed that society is in a new era - a zeitgeist age of rising populism (Moffit, 2016) wherein, it is argued, that the concepts of liberalism and democracy are becoming increasingly disconnected from each other (Foa \& Mounk, 2016). This inherent negative undertone, partly stems from what is perceived as an adverse consequence of globalisation, one in which technology has played an instrumental part of opening up the world, and, hence being at the forefront of this change. This has subsequently and ironically led to what has been purported as democracy being in retreat. Additionally, this divide has largely been directed towards the world governments; whereby, it is debated that there is a growing disconnect between citizens and their elected leaders. The UK is certainly no stranger to this concept both internally and questionably within the continent it is in. A manifestation of this, debatably resulting in Britain, in 2016, choosing to leave the European Union and wanting to return to a somewhat insular approach (Fox, 2016c).

Mounk $^{3}$ speaking in 2017 (at The Chicago Council of Global Affairs) stated, "[c]itizens have fallen out of love with democracy in a deep way;" and, hence, the interpretation between the public and the police relationship, invariably, stands to be theoretically challenged as a result of the peoples' wider disenchantment of the current political environment. The divide, as to

\footnotetext{
${ }^{3}$ Mounk (making reference to his 2018 publication - The People vs. Democracy, Why Our Freedom Is in Danger and How to Save It. Harvard University Press).
} 
Accepted 10 September 2018 (Journal - Technology in Society)

Accepted manuscript available online: 21-SEP-2018

https://doi.org/10.1016/j.techsoc.2018.09.006

where the police stand in terms of politics has often been questioned, no doubt due to the fact that the role of the police also entails upholding laws, which have been passed by Parliament and hence politicians.

Such sentiments inevitably lead to the questioning of, or the potential consequences to, the relationship between the police and the public, particularly given that the police are often viewed as an agency of the government that citizens are most likely both to see and have contact with.

In the UK, unlike many other police forces and services across the globe, the police remain officers of the Crown whereby during attesting to become a police officer, they swear an oath of allegiance which recognises that they "truly serve the Queen in the office of constable." This is "with fairness, integrity, diligence and impartiality, upholding fundamental human rights and according equal respect to all people" (Police Reform Act 2002, Sct. 834). Yet this division is often misunderstood by the citizens they serve who often perceive the police to be an extension of the State and therefore of the State government of the day.

This paper commences by considering this interpretation or misconception firstly, and the backlash that is often experienced and encountered by the police as a consequence of such, which, inexorably stands to be intensified during a period of political tension and/or government distrust. In doing so, contextualisation is provided concerning the development of the police in the UK with comments being made as to the wider progressions of society and the impacts on the police and on policing. It remains a fact that the past invariably affects the future from both a positive and negative stance. It also remains true that the police have

\footnotetext{
${ }^{4}$ Replacing Schedule 4 to the 1996 Police Act (- Section. 29)
} 
Accepted 10 September 2018 (Journal - Technology in Society)

Accepted manuscript available online: 21-SEP-2018

https://doi.org/10.1016/j.techsoc.2018.09.006

had to adapt to the expectations of society as well as implement systems to aid them in their changing and ever-challenging role. Part of this evolutionary process has seen the use,

implementation and arguably 'now' dependency on various technologies, which at times, has resulted in public scepticism, further distrust, and even abhorrence, of the police service.

The main thrust of this paper is given to policing in the dawn of a 'new' technological age, which debatably runs alongside a new political era for society. 'Trust' remains a key concept of change and development - and may be viewed as a driver for and enabler of advancement; and yet, conversely, mistrust could be seen to be an obstacle and inhibitor.

In considering these aspect, the primary focus point for the discussion is given to (historical) technological developments - particularly (police) surveillance and the use of Close Circuit Television methods. The latter discussions then turn to 'drones' and how they will be used by society going forward - which includes also by the police. The utilisation of drones is set to soar in coming years and the use of this technology presents both challenges and opportunities to the police, not least due to the lack of a consistent regulatory approach (Fox, 2017). ${ }^{5}$ From this perspective the police will no doubt potentially be a user and also a regulator of their use. Yet, like other technologies used by the police, there will invariably also be debate and criticism levied against police utilisation over the coming years. This largely emanates from distrust of the police and/or stems back to the interpretation of the independence of the police from the executive - the politicians in government; this, therefore stands to manifest itself in terms of accountability, legitimacy and transparency as to the use of such technology.

\footnotetext{
${ }^{5}$ This paper was a development of a presentation made to the United Nations in 2017:

S. J. Fox: Hacked Off - by the drive for autonomy. Safety, Security and Disasters. WSIS Forum EC Medici Framework. 12-16 June, 2017 - UN, Geneva
} 
The design of this research is based upon a mixed-methods, cross-disciplinary approach, whereby the developments in society are considered from a historical perspective which also interjects against a naturalist/anthropological approach, providing a contemporary analysis theory to show a symbiotic relationship between society, technology and the police. This provides the backdrop by which to discuss the future use of drones within society, the challenges of this growth market - particularly from a policing perspective; and, the developing use within a policing role.

Data and case-studies are used to support the arguments presented in the final section of this paper.

\section{Historical Contextualisation: $A$ symbiotic revolution! ${ }^{6}$}

During the eighteen century the older models of policing in England were viewed as failing to cope with the then contemporary challenges of the day (Joyce, 2011: 6). Yet, despite this, there was considerable reluctance to undertake reforms. One primary reason for such was the fear that policing would come under the central control of government and that this would

\footnotetext{
${ }^{6}$ In the context of this paper reference is made to four industrial revolutions. It should be noted that there remains some discrepancies and disagreements as to whether we are on the doorstep of a fourth or fifth revolution.

The authors of this paper adhere to the principle of the dawning or entry into the fourth, as per the more accepted viewpoint - namely:

1. Mechanical

2. Electrical

3. Digital

4. Virtual

5. Neural (and/or the combination of virtual, robotics with the human interface)

For a contrast of opinion see the following: https:/www.quora.com/What-would-be-the-5th-industrialrevolution-like-We-are-already-going-through-the-4th

https://www.economist.com/node/21553017

http://www.genpact.com/insight/blog/the-fifth-industrial-revolution

http://www.702.co.za/articles/297629/the-5th-industrial-revolution-bizun
} 
Accepted 10 September 2018 (Journal - Technology in Society)

Accepted manuscript available online: 21-SEP-2018

https://doi.org/10.1016/j.techsoc.2018.09.006

result in the curtailment of rights, whereby the police would be used "to crush the liberties of the people" (Sir Robert Wilson, quoted in Rawlings, 2002:123). However, running alongside this was the fear of the military and, hence the potential creation of a full-time quasi-military police force.

The industrial revolution had led to further challenges for the policing system of the day, on what was viewed as a dysfunctional system of policing with low numbers of constables for an often-transient population. Critchley (1978: 21) offers that 'the breakdown in law and order marched in step with the industrial revolution.' So, whilst, on the one hand, there was clear improvements to society through the development of technology, on the other hand, society was negatively affected through growing disorder and the rise of contemporary crimes. The mobilisation of the military during earlier riots, such as the 1780 anti-Catholic Gordon riots, had led a high number of the protestors being shot and killed. Inevitably, despite the reluctance to see the police reformed, the fear of further deaths at the hands of the military, who were called in to maintain public order, presented, what was viewed as, the lessor of these two-evils.

From this perspective there is clear interdependency to a civil and peaceful society and the establishment and role of today's (contemporary) police in England (and Wales). Not least it is worth reinforcing that the police remain, today, routinely unarmed (including within situations of high disorder) - no doubt a conscious response to the deaths wherein the military had been deployed.

The word "symbiosis" was allegedly first used by Albert Bernhard Frank in 1877, whilst the more developed meaning was arguably provided by Anton De Bary (1879) who defined it as 
Accepted 10 September 2018 (Journal - Technology in Society)

Accepted manuscript available online: 21-SEP-2018

https://doi.org/10.1016/j.techsoc.2018.09.006

a relationship and interaction between two different entities that have clear links and dependencies to each other. From this viewpoint there was a strong need for an effective police service to be established as a consequence to growing disorder and deviance emanating from a more transitory population which was invariably linked to technological advancements. Therefore, there is clear reasoning to advocate that the industrial revolution was in fact the catalyst that led to the evolution of the police, and, in the form that is still recognised today. Furthermore, it could also be advocated that from this period onwards, that technology was to be ever-embedded into the police service as a reflection of societies greater needs. However, society has continued to carry with it a modicum of distrust of the police, which has extended, at times, to the utilisation of certain technology and arguably advancements of the police service in what is a changed era to Peel's time.

\subsection{Policing by consent}

There is no doubt that the formulation of the capitals 'new' police force ${ }^{7}$ required careful thought and management in order to achieve support and buy-in from the public of the day. Whilst, it could controversially be argued that Robert Peel did base his (circa 1829 Metropolitan Police) model on the military in terms of organisation and the administrative structure, the uniform was nevertheless purposely distanced from the familiar red of the military in terms of being a distinctive blue 'police uniform'. Emphasis was importantly accorded to officers being regarded as citizens, albeit in uniform, who exercised their powers to police with the consent of their fellow citizens. In this way a clear connect was applied to the public and the police in terms of a consensual and interrelated relationship; and, from this basis stemmed the nine (or arguably even twelve ${ }^{8}$ ) policing principles, which have also been

\footnotetext{
${ }^{7}$ Excluding the central city square mile.

${ }^{8}$ See the discussions within:

R. Bohm and K. Haley (2008) Introduction to Criminal Justice. McGraw-Hill Higher Education And K. Peak (2009) Policing America: Challenges and Best Practices. Pearson/Prentis Hall
} 
Accepted 10 September 2018 (Journal - Technology in Society)

Accepted manuscript available online: 21-SEP-2018

https://doi.org/10.1016/j.techsoc.2018.09.006

attributed to Peel. That said, it has also been identified that Robert Peel is unlikely to have actually written out or articulated these principles (Grieve, 2015:18) and it therefore more likely that these principles stemmed from the first Commissioners of the Police of the Metropolis (Charles Rowan and Richard Mayne) than from Peel. Rowan, in particular, is said to have previously written on policing values, having also had a distinguished military career before assuming the post jointly as one of the first Commissioners in the Metropolitan Police. Grieve (2015:19) states that the military paradigm continues to lie at the heart of many debates about policing and police leadership from the early origins through to the present day. From this perspective it could be reasoned that these thoughts are perhaps even genetically embedded in the publics' perception of the police and are an extension of the inability to see the police separately from the government - invariably both these factors remaining a barrier of the wider society towards fully trusting the police.

Rowan, given his military background and discipline, is equally attributed as drafting the initial Instruction Book that outlined the demeanour, tasks and duties of the Office of Constable under the Crown, these however, built upon interpretation as to the best practice that had gone before.

From this perspective the significance of history in the development of the 1829 changes, through to the current time, cannot be forgotten or disregarded. Perhaps none more so than the 'General Instructions' given to the police officer. As Charles Reith stated in his 'New Study of Police History' (1956) these Instructions were 'unique in history and throughout the world because it derived not from fear but almost exclusively from public co-operation with the police, induced by them designedly by behaviour which secures and maintains for them the approval respect and affection of the public.' 
Accepted 10 September 2018 (Journal - Technology in Society)

Accepted manuscript available online: 21-SEP-2018

https://doi.org/10.1016/j.techsoc.2018.09.006

In essence, this was a form of democratic policing, reflective of the wider democratic society, which favours equal rights, freedom of speech and a fair trial whilst tolerating the views of minorities. From an inter-dependency - linked perspective, 'defining such a society is a police force that 1) is subject to the rule of law, rather than the wishes of a powerful leader or party 2) can intervene in the life of citizens only under limited and carefully controlled circumstances and 3) is publicly accountable' (Marx, 2001).

Albeit, this said, society in the $19^{\text {th }}$ century was noticeably different than it is today.

\subsection{2. 'General Instructions' and public opinion}

The General Instructions - the Peelian Principles ${ }^{9}$ refer to the role of the police and how their duties are to be undertaken. Reference is made to various responsibilities; however, clearly cited at the outset is, 'the prevention of crime and disorder' and the role the police undertake as an alternative to the 'repression by military force.'

The emphasis throughout the principles is that the functions and duties of the police are 'dependent on public approval,' for the very existence of this office is consequently dependent upon the ability to 'maintain public respect.' The 'willing co-operation of the public' is an essential principle in ensuring the observance of laws. It is acknowledged however, that co-operation and the use physical force sit at the two polar ends of a spectrum. And, whilst it is said that the objective remains to 'seek and preserve public favour' by conduct which is impartial, namely, which complies with policies and justice and which is not influenced by social standing, friendship or wealth - it is also said that this should also not be through 'pandering to public opinion.'

\footnotetext{
${ }^{9}$ See the definition as within: https://www.gov.uk/government/publications/policing-by-consent/definition-ofpolicing-by-consent [accessed 1 April, 2018].
} 
At times, public opinion has been a positive driver in changing the direction of policing and reinforcing the fact that the police need to represent and be representative of the society they work within. Accountability of police actions and the standards of the police have continued to receive more scrutiny in the last fifty or so year due to high profile events. This is also due to technological advancements which have provided the more extensive and open platform, for not only transmitting information and events, but viewing real-time action as it unfolds.

Likewise, since the $18^{\text {th }}$ century industrial revolution (which is now interpreted as the first industrial revolution) the physical mobility of people has not only continued but considerably intensified, not just within the UK but internationally. This has invariably resulted in changes to the ethnicity and national identity of the population. ${ }^{10}$ Significantly, this has been due to several key technological developments and the ease of travel, such as the automobile and the aircraft. In fact, it is proclaimed that when Henry Ford mastered the moving assembly line which led to mass production of the car, the second industrial revolution commenced. ${ }^{11}$

Travel became both faster and more extensive through the later advancement of the aeroplane (especially the commercial jet). The latter, particularly noticeably, having a symbiotic relationship to turbulent, violent events. The evolution of the aircraft was no doubt hastened through the use and development in warfare, which later resulted in commercial use for both freight and passenger movements (Fox, 2014). The First and Second World Wars also resulted in the displacement of communities and the movement of races and religious within

\footnotetext{
${ }^{10}$ Office of National Statistics: https://www.ons.gov.uk/peoplepopulationandcommunity/populationandmigration/populationestimates/articles/o verviewoftheukpopulation/july2017 [accessed 3 April, 2018].

${ }^{11}$ The Economist on Line: The third industrial revolution. April, 21, 2012.

https://www.economist.com/node/21553017
} 
Accepted 10 September 2018 (Journal - Technology in Society)

Accepted manuscript available online: 21-SEP-2018

https://doi.org/10.1016/j.techsoc.2018.09.006

States and also into other nations. And, whilst historically this was not a new phenomenon, there is little doubt that transport has aided and intensified this through the ease of movement; and, at the same time, this has resulted in consequences to policing which has made it more challenging and demanding.

\section{Evolution: Technology and the Police}

The development of technology is an evolutionary process that builds upon previous advancements. This closely aligns to natures evolutionary process and the theory advocated by Charles Darwin, whereby there is a selection process that sees a gradually changing system develop, albeit, in nature, through the accumulation of random mutations. ${ }^{12}$ Whilst the industrial changes, which started about 1760, led to the development of new manufacturing processes, it is questionable whether this transition was really a revolution as opposed to evolutionary progression. Whilst there is no set period to define a revolution, the difference between evolution and revolution is that the foremost normally is synonymous with a gradual and continuous development including in respect to beliefs, morals and ideas. Revolution, on the other hand, is said to imply changes which are more sudden in their nature and action, and, is also said to entail some sort of catastrophe or negative consequence. In terms of time, it is recognised that the first industrial revolution spanned a period of just under 100-years, so perhaps it is a misnomer in terms of the catastrophic outcome(s) of technological advancements. ${ }^{13}$

\footnotetext{
${ }^{12}$ Charles Robert Darwin was an English naturalist (1809-1882). http:// darwin-online.org.uk [Accessed 30 April 2018].

13 The term Industrial Revolution was first popularised by the English economic historian Arnold Toynbee (1852-83) to describe Britain's developments in the period from 1760 to 1840.
} 
Accepted 10 September 2018 (Journal - Technology in Society)

Accepted manuscript available online: 21-SEP-2018

https://doi.org/10.1016/j.techsoc.2018.09.006

That said, at times, particularly when new technology has been implemented by the police in the $20^{\text {th }}$ and $21^{\text {st }}$ centuries, concerns have certainly been raised as to both the need and perpetually the potential consequence of their use.

\subsection{A stick and a whistle!}

A police constable today, walking 'his' beat with a stick for protection and a whistle for communications would surely be questioned in terms of the officer's ability to effectively and efficiently undertake 'his' duties. Had policing not evolved in line with society there would no doubt be the underlying 'situation' that all the police officers today would remain 'white' men; and, in today's society this would stand, rightly so, to be challenged in terms of the polices' ability to keep pace with the times and be reflective of current demographics. Society evolves in the way it thinks and this directly links to the acceptability of practices and behaviours. As Bilz and Nadler (2014) state, the norms of professionalism have moved towards equality which reflects the majority of the publics' shifting attitudes and "behaviour and attitudes that would have not only [been] acceptable, but normal, just a couple of decades ago, are now anathema."

Goethe identified, human beings are part of a natural continuum (Bell, 1994). Norms and values within societies change and adapt as part of an evolutionary process. Invariably there is a requirement for policing to advance and evolve, and to be reflective of the society served.

That said, in terms of representation of the communities,' criticism is still levied at the police, in terms of disproportionate numbers reflecting a multi-cultural society; and yet, conversely when the police mirror society and keep pace with technological advancements they become subject to further challenges in terms of necessity and the potential consequences of their actions. 
The General Instructions given to police officers clearly recognised that police remain members of the public who undertake duties in the 'interests of community welfare and existence.' Hence, when this is considered, the logical consequence is that they should not be disadvantaged or hampered by non-utilisation of technological resources which the wider community utilise.

Today, the police are recognised to have the following core operational duties (amongst others) which include:

- $\quad$ protecting life and property;

- preserving order;

- preventing the commission of offences; and,

- $\quad$ bringing offenders to justice. ${ }^{14}$

Their ability to undertake these duties is now ever dependent upon technology. Whilst the, circa 1829, Peelian Principles could not envisage the growing need for police to utilise technology in their role, reference is made to the fact that 'the test of police efficiency is the absence of crime and disorder' which today necessitates utilisation of tools and equipment to aid them achieve this goal.

\subsection{Yesterday's technology}

New technologies undoubtedly have a significant impact to both changes and development within society. Winner (1997) argues that society views technologies in a utopian context,

\footnotetext{
${ }^{14}$ College of Policing: https://www.app.college.police.uk/app-content/operations/operational-planning/coreprinciples/
} 
Accepted 10 September 2018 (Journal - Technology in Society)

Accepted manuscript available online: 21-SEP-2018

https://doi.org/10.1016/j.techsoc.2018.09.006

noting that "the basic conceit is always the same: new technology will bring universal wealth,

enhanced freedom, revitalized politics, satisfying community, and personal fulfillment".

However, it is contended that concerns and even fear exist as to the use by the police of certain technology, and, at times this has hampered the effectiveness of their use in the fight against crime. Conversely, and at the same time however, criminals continue to exploit such technological advancements. As Nuth (2008) explains, “criminals use new technologies to facilitate and maximise criminal activities, while police use new technologies to do the opposite, i.e. minimising or controlling criminal activities." Taking this into account, it is perhaps ironic that there has been such public scepticism as to both the acceptance and use of certain new technology employed by the police.

That said, according to Lindsay et al (2014), the acceptance of technology used in policing has and continues to actually be under-researched. This is reinforced by reference to Bouwman \& van der Wijngaert, (2009) Colvin \& Goh, (2005) and Hu, Lin, \& Chen, (2003) the latter of which specifically addresses this in terms of the acceptance of technology and their use by police officers themselves.

Since the 1960's technology has become an important part of today's policing in the UK. Newburn and Neyroud (2013) state that one of 'the most important pieces of legislation affecting policing' was the 1964 Police Act (The Act). ${ }^{15}$ Whilst these comments are no doubt aimed at the wider overarching implications of the $\mathrm{Act}^{16}$ - The Act also undoubtedly paved the way for the need and use of advancing technologies.

\footnotetext{
${ }^{15}$ Police Act 1964 (1964 c.48).

${ }^{16}$ The Act was far reaching and considered, amongst other factors, the structure and organisation of the police namely, aspects of professional policing, police autonomy and accountability, democratic governance and the shift in power from local to central control.
} 
Accepted 10 September 2018 (Journal - Technology in Society)

Accepted manuscript available online: 21-SEP-2018

https://doi.org/10.1016/j.techsoc.2018.09.006

The Unit Beat system was actually born out of these changes which were aimed at professional policing and increasing effectiveness. This new 'method' of policing called for the use of motorised patrols "accentuated by the technology of fast cars, sirens and flashing blue lights" (Reiner, 2010:79). The specialisation of policing units were developed together with other technologies to support these, for what was said to be necessary 'keys' for winning the 'fight against crime' (Reiner, 2010:79). The changes in policing were initially supported by the public (Weatheritt, 1986). This was largely due to the fact that they portrayed as providing a faster emergency service with improvements in detecting crime, however, the mood quickly changed to one of political controversy with the police becoming embroiled in the politicisation of relations with the public (Holdaway, 1977).

Today, the mobility of the police, in terms of utilisation of vehicles, as part of the day to day role, is 'generally' accepted, certainly the use of blue lights and sirens has become an everyday feature of all emergency services in the UK. Whilst, to perhaps the older population, fire brigade policing arguably remains somewhat controversial, perceived to have been a backward step, removing the walking 'Bobby' from the streets into a metal case isolated from the public.

However, other technology emanating from the 1960's has tended to provoke even more anxiety, arguably of a different nature, namely in relation to privacy concerns and the possible curtailment and breach of human rights. This, no doubt, has links back to the original fear that policing would, as it has done, move to a centralised model and that alongside this, citizens' rights could become compromised. In essence, this stems from an early fear of the military and a concern that the police would become a quasi-military version 
Accepted 10 September 2018 (Journal - Technology in Society)

Accepted manuscript available online: 21-SEP-2018

https://doi.org/10.1016/j.techsoc.2018.09.006

of such, who would be used "to crush the liberties of the people" (Sir Robert Wilson, quoted in Rawlings, 2002:123). ${ }^{17}$ It is therefore somewhat ironic perhaps that a high percentage of technology used today in policing actually originates from military development and utilisation.

\section{Paradoxes: Wars, the military and human rights}

There is little doubt, that wars and military development of technology have made a major impact on policing, particularly since and as a result of the Second World War (1939-1945), which potentially coincides with what has been recognised, by some commentators as the commencement of the Third Industrial Revolution: (c. 1940 - 2008). ${ }^{18}$ This has been proclaimed as the period which largely led to developments in the 'computer, the internet, self-publishing and sophisticated communication devices. ${ }^{19}$ Nunn (2001) confirms that advanced technologies, such as biometrics, digital imaging, and other surveillance approaches, originally developed for the military are now commonly used by the police.

However, the end of the second World War was no doubt equally significant for another reason, namely for driving the fight to recognise the rights of individuals, and, which led to the world becoming united on establishing minimum standards of dignity to be afforded to all human beings. These standards became known as human rights, which were recorded in the United Nations Declaration of Human Rights. ${ }^{20}$

\footnotetext{
${ }^{17}$ See section 2. Historical Contextualisation: A symbiotic revolution!

${ }^{18}$ See: Jon Gulson, Blockchain and a Brief History of Industrial Revolutions for the ICO Investor

- https://hodlthemoon.com/blog/blockchain-and-a-brief-history-of-industrial-revolutions-for-the-ico-investor. 10 July 2017

${ }^{19}$ Ibid.

${ }^{20}$ See the United Nations website at http://www.un.org/en/sections/issues-depth/human-rights/

Also see: https://rightsinfo.org/universal-declaration-human-rights/
} 
Accepted 10 September 2018 (Journal - Technology in Society)

Accepted manuscript available online: 21-SEP-2018

https://doi.org/10.1016/j.techsoc.2018.09.006

Whilst many of the rights are particularly pertinent and relevant to the role undertaken by the police, the use of technology used for policing purposes is often challenged as being in conflict to Article 12, which states,

"No one shall be subjected to arbitrary interference with his privacy, family,

home or correspondence, nor to attacks upon his honour and reputation.

Everyone has the right to the protection of the law against such interference or attacks. $" 21$

\subsection{Surveillance}

Perhaps somewhat controversially, it could be argued that the early General Instructions given to police officers, potentially pointed to covert tactics being implemented, and even accepted, in order to achieve the wider objective of a safe society - wherein, reference was made to the outcome and 'not the visible evidence of police action in dealing with them.' ${ }^{22}$ In today's society this is, however, somewhat of a contentious approach, whereby accountability and the maintenance of rights have risen to the surface of policing today and the tactics utilised, including the use of advancing technology, remain highly subject to public discussions and scrutiny.

Surveillance technology was used around the mid 1940's, when Germany began using surveillance systems to monitor their missiles and rockets. The technology was soon embraced by the United States (USA). And, by the 1950s Great Britain began to use a similar monitoring system - Close Circuit Television (CCTV) technology. Whether or not this was surveillance as such, is perhaps a matter of interpretation. The EU defines the concept of surveillance, 'as the remote observation of people by electronic means', so from this

\footnotetext{
${ }^{21}$ At the regional level, the right to privacy is protected by the European Convention on Human Rights (Art. 8).

${ }^{22}$ As above (section 2.1.2 of this paper) and the definition as within: https://www.gov.uk/government/publications/policing-by-consent/definition-of-policing-by-consent [Accessed 1 April, 2018].
} 
Accepted 10 September 2018 (Journal - Technology in Society)

Accepted manuscript available online: 21-SEP-2018

https://doi.org/10.1016/j.techsoc.2018.09.006

perspective CCTV provide the means to undertake this. ${ }^{23}$ By the $1960 \mathrm{~s}$, CCTV was used for the first time by the Metropolitan Police to monitor events or rallies particularly those attended by the Royal Family, or the Prime Minister, whilst London streets later began to gradually deploy permanent surveillance devices.

The 1990's is particularly attributed to establishing the current legacy of CCTV systems throughout the UK. This coincided with the conflicts in Northern Ireland and the fears for further escalation of violence by the Irish Republican Army (IRA) on the British mainland.

In many ways, the technology was sold and portrayed to the public as a means to keep society safe and secure - with perhaps the secondary objective, namely, the effective means to gather 'relevant' intelligence being somewhat less coherently stated.

Surveillance technology, arguably remains a preventive measure, whereby the system provides the means to induce conformity to expected behaviour patterns, with persons, aware that they are being watched, more likely to behave in a way the majority of society expects (Padgett et al, 2006). Nuth (2008) is of the opinion that CCTV was therefore introduced with the intention to reduce crime, and, viewed from this perspective, states, to some extent, it has been successful in doing so.

That said, the terrorist attacks in London in 2005 led to questions and debates in respect to the use and effectiveness of CCTV. Following the explosions on 7 July 2005, the identification of the four suicide bombers strongly relied on CCTV footage. This led to camera surveillance technology gaining further prominence as a measure advocated for

\footnotetext{
${ }^{23}$ EU Science Hub - https://ec.europa.eu/jrc/en/research-topic/surveillance [Accessed 26 April, 2018].
} 
Accepted 10 September 2018 (Journal - Technology in Society)

Accepted manuscript available online: 21-SEP-2018

https://doi.org/10.1016/j.techsoc.2018.09.006

counterterrorism purposes but, at the same time, it was stressed that CCTV remains one of the most controversial instruments in security policies (Stutzer and Zehnder, 2013).

Overtime there have been concerns as to the 'over surveillance' of society and, today, with stricter data protection rules coming into play, surveillance systems remain controversial. ${ }^{24}$ It has been argued by some that complete surveillance could easily lead to a "dictator-type situation where simply 'watching' eventually turns into 'dictating' behaviour' (Nuth, 2008). ${ }^{25}$

Increasingly, people are surrounded by intelligent sensors and intuitive interfaces are being embedded in all kinds of objects, which have a multitude of operations, not least monitoring and tracking people and their location. Likewise, surveillance has been extended to include innovations in technology that include communication surveillance. The transition from fixed-line telephone systems to portable telecommunication resulted in dramatic growth in mobile phone usage and, the continuing development of the Internet saw the birth of a number of new tools from which to communicate with little to no costs. These advancements have enabled greater connectivity, facilitated the global flow of information and ideas, and increased the opportunities for economic growth and societal change. Nonetheless, at the same time, technology advancements provided the means to monitor private communications, particularly at a State and arguably police level, which in itself leads to controversy. $^{26}$

\footnotetext{
${ }^{24}$ Regulation (EU) 2016/679 of the European Parliament and of the Council of 27 April 2016 on the protection of natural persons with regard to the processing of personal data and on the free movement of such data, and repealing Directive 95/46/EC (General Data Protection Regulation) (GDPR) OJ L 119, 4.5.2016, p. 1-88. ${ }^{25}$ Nuth referring to: Federal Debt Relief System, Is Democracy for Everyone Where Surveillance Rules? Available on: http://www.fdrs.org/is_democracy_for_everyone.html\#top.

${ }^{26}$ In the first judicial validation of wiretapping, in the United States, Justice Brandeis of the (United States) Supreme Court noted that wiretapping was a "subtler and more far-reaching means of invading privacy" and stated that it could not be justified under the Constitution. Olmstead v. United States, 277 U.S. 438 (1928).
} 
Accepted 10 September 2018 (Journal - Technology in Society)

Accepted manuscript available online: 21-SEP-2018

https://doi.org/10.1016/j.techsoc.2018.09.006

Today's CCTV systems have also advanced substantially, in terms of technology

developments, from the earlier ones utilised in the 1990's. And, in many ways they are

perhaps more controversial than their forerunners. The technology still allows actions to be coordinated at a distance but combines photonics, thermal imaging, facial and behavioural recognition capabilities.

Britain is generally recognised to be one of the most monitored nations in the world. Liberty identifies that, whilst figures are hard to come by, it is estimated that Britain is monitored by as many as 5.9 million CCTV cameras. ${ }^{27}$

Systems monitored for policing purposes have historically and predominately tended to be fixed. Over recent times these systems have become devolved to other agencies and private companies/providers who monitor the CCTV systems in public places and alert the police to incidents or suspicious events. The operators are also approached by the police to check specific times and locality for persons of interest.

However, CCTV use is also spreading. It is no longer restricted to static police use in public places but utilised in private property, shops and city centres, as well as being routinely rolled out in school, bars, pubs, and leisure facilities. The police also increasingly wear body cameras $^{28}$ for recording footage, and at times this use has been controversial and subject to challenge. That said, CCTV is, in essence, part of our everyday lives and one, by enlarge, the majority of people are accepting of it for legitimate police purposes. Citizens are increasingly personally utilising the technology to protect themselves and their property and to provide evidence in civil or criminal proceedings. The use of mobile phones to capture live

\footnotetext{
${ }^{27}$ Liberty: https://www.libertyhumanrights.org.uk/human-rights/privacy/cetv-and-anpr [Accessed 27 April, 2018].

${ }^{28}$ Also, known as body-worn video.
} 
Accepted 10 September 2018 (Journal - Technology in Society)

Accepted manuscript available online: 21-SEP-2018

https://doi.org/10.1016/j.techsoc.2018.09.006

synchronous footage and dash-cams mounted in the car are becoming common everyday practices.

Whilst concerns may have been raised as to the use of surveillance techniques by national governments, no doubt intensified due to George Orwell's vision of a 'Big Brother' State (one, which constantly monitors every citizen through constant surveillance ${ }^{29}$ ) the combined video and facial recognition technologies are arguably utilised to keep society safe and secure. They constantly "alerts officials to the possible presence of a person of interest, such as a criminal, missing person, fugitive, abducted child, or terrorist" (Rossmo, 2000:56).

\subsubsection{Actions and Reactions}

Isaac Newton stated, to every action there is an equal and opposite reaction (Newton's third law of motion and the law of universal gravitation ${ }^{30}$ ). As surveillance becomes more and more pervasive, the equal and opposite reaction will necessitate that data protection and privacy issues will become even more important and yet, intensively also more complicated. ${ }^{31}$ Whilst the increasing use of advancing technology will, nevertheless, need to be balanced with appropriate provisions and protections strengthened and, arguably, put in place, the enormity of this task should not be underestimated. Invariably this task will be one for the States' Governments to manage, be it at a national, regional or international level.

Yet, as technology continues to evolve, it will increasingly also fall into the wrong hands, utilised for criminal purposes that will become equally a challenge for the police to manage. Criminal activity perpetrated using the internet clearly demonstrates new and emerging crimes. As was said from the outset, achieving equilibrium between what the public want,

\footnotetext{
${ }^{29}$ George Orwell's classic novel - Nineteen Eighty-Four, first written in 1949.

${ }^{30}$ Sir Isaac Newton (1643-1727), English physicist and mathematician. http://www.biography.com/people/isaac-newton-9422656 [Accessed 28 March 2018].

31 These discussions fall outside the remit of this paper.
} 
Accepted 10 September 2018 (Journal - Technology in Society)

Accepted manuscript available online: 21-SEP-2018

https://doi.org/10.1016/j.techsoc.2018.09.006

expect and even 'demand' of their police and what is feasible and realistic remains a difficult act to balance. This necessitates support from both the government and the public.

The right to privacy exists as a safeguard to citizens which includes intrusion into a persons' personal life. The right to privacy can only be limited in a democratic society, by law, when it is necessary for reasons such as national security, public safety, the prevention of crime or protection of the rights and freedoms of others. Any limitation on this right must be proportionate.

The role of the police however remains to:

- $\quad$ protect life and property;

- preserve order;

- prevent the commission of offences; and,

- $\quad$ bring offenders to justice. ${ }^{32}$

\subsection{Policing Challenges - Technology: costs, efficiency and public acceptance......}

Increasing the police remain 'stretched' and with an 'ever-thin blue line' being deployed on the ground. Their abilities to respond to crime and the other challenges that society presents is also both time consuming and costly. One of the greatest challenges for the police going forward will undoubtedly be policing of the cyber space and the technology which forms part of the new (fourth) industrial revolution (Fox, 2016 and 2017). ${ }^{33}$

\footnotetext{
${ }^{32}$ College of Policing: https://www.app.college.police.uk/app-content/operations/operational-planning/coreprinciples/

${ }^{33}$ Papers develop on from the discussions at the UN:

S. J. Fox; Challenges for the future: preparedness! - In the face of cyber-terrorism. Safety, Security and Disasters. WSIS Forum EC Medici Framework. 2-6 May, 2016 - UN, Geneva.

S. J. Fox: Hacked Off - by the drive for autonomy. Safety, Security and Disasters. WSIS Forum EC Medici Framework. 12-16 June, 2017 - UN, Geneva.
} 
Accepted 10 September 2018 (Journal - Technology in Society)

Accepted manuscript available online: 21-SEP-2018

https://doi.org/10.1016/j.techsoc.2018.09.006

Currently, it is recognised that society stands at the threshold of this new (fourth) industrial revolution, wherein it is recognised that the five key technologies that will drive this next industrial revolution. These technologies are robotics, artificial intelligence (AI), further automation of an advanced nature and the Internet of things (IoT). ${ }^{34}$ Eventually, they will form part of societies accepted day-to-day living and will also therefore undoubtedly, likewise, be utilised by the police. But as history has shown us - acceptance by the public of police use may require careful management.

Novel, intelligent, efficient, "cool gadgets and tools"35 - including secure surveillance systems that will increase the safety and security of citizens, whilst respecting fundamental rights, will be essential in this new era and as we advance forward in the $21^{\text {st }}$ century. Police mobility remains key to this objective and, yet, itself remains a challenge in what has become a progressively busy society. Police increasingly need to keep communities safe and secure and sometimes without the demand of a direct physical appearance.

The police use of helicopters is certainly not novel; and, from a policing perspective, their use is rarely questioned by society. However, helicopters utilise a variety of technological systems such as thermal and digital imagery and undertake surveillance operations.

They provide an 'eye in the sky' and the means to fly above territory that may be difficult to access or to watch (such within cities and for crowd control purposes). Air transport is quick but expensive to operate. That said, the police increasingly rely on air support for their day to

\footnotetext{
${ }^{34}$ See reports from May, 2018:

https://cointelegraph.com/news/us-mutual-fund-vp-says-blockchain-will-help-drive-this-next-industrialrevolution

"The blockchain is an incorruptible digital ledger of economic transactions that can be programmed to record not just financial transactions but virtually everything of value." Don \& Alex Tapscott, authors Blockchain Revolution (2016): https://blockgeeks.com/guides/what-is-blockchain-technology/

${ }^{35}$ Taken from a presentation given at the United Nations - S. J. Fox: Policing Society: Utilising "cool gadgets and tools." Safety, Security and Disasters - UN, Geneva. 19-23 March, 2018. (WSIS Forum - EC Medici Framework).
} 
Accepted 10 September 2018 (Journal - Technology in Society)

Accepted manuscript available online: 21-SEP-2018

https://doi.org/10.1016/j.techsoc.2018.09.006

day operations; and, between 1993 and 2009, the number of forces with access to air support more than doubled. However, the biggest change came in 2012, when the National Police Air Service (NPAS) was formed to centralise the provision of air support and make it more efficient. However, whilst savings were made, it was largely as a result of cutting the service provided to forces. As a result, there is some evidence to suggest that police officers and services are making less use of air support because it takes too long to arrive due to the cuts in these provisions. ${ }^{36}$

The conclusions of a recent Her Majesty's Inspectorate of Constabulary and Fire Rescue Services (HMICFRS) enquiry stated that, there was "strong indications that the police service now operates insufficient aircraft to provide consistently prompt responses to incidents in all forces in England and Wales." ${ }^{37}$ The call-outs largely being recognised to be for "response policing" and to additionally "provide support for counter-terrorism purposes and some limited support to operations to combat serious and organised crime." 38

As a result of the difficulties in obtaining air support, HMICFRS also acknowledged that some forces have turned to different technology and have been investing in drones, as an alternative to using NPAS. However, societies acceptance of drones used by the police may yet be fraught with difficulties, given their historical links to warfare and covert operations including surveillance, reconnaissance and air strikes. In essence, this is yet again another challenge - a legacy of military use and government sanctions and hence, distrust.

\section{Drones}

\footnotetext{
${ }^{36}$ HMICFRS: 'Since 2009, the number of police aircraft has been reduced from 33 to 19 and there has been a reduction of about 45 percent in the number of hours flown.' Her Majesty's Inspectorate of Constabulary and Fire Rescue Services. November 2017. www.justiceinspectorates.gov.uk/hmicfrs [Accessed 1 April, 2018] ${ }^{37}$ Ibid.

${ }^{38}$ Ibid.
} 
Accepted 10 September 2018 (Journal - Technology in Society)

Accepted manuscript available online: 21-SEP-2018

https://doi.org/10.1016/j.techsoc.2018.09.006

Drones are by no means new technology. In 1946, the American magazine Popular Science said that "[d]rones, as the radio-controlled craft are called, have many potentialities, civilian and military." ${ }^{39}$ Once again there is a synergy to warfare with regards to both development and use. While the military and border authorities have long been using unmanned aerial vehicles (UAV's), unmanned combat aerial vehicles (UCAV), and drone aircraft in their respective roles, the use of civilian unmanned aircraft is relatively newer in comparison (Fox, 2017). That said, it is widely recognised that this is set to change over the coming years, with innovative usage of drones looking to become part of the everyday civilian remit.

The EU identifies that there are already more than 1,700 different types of drones produced by official manufacturers (with approximately one third made in the EU). ${ }^{40}$ Predictions are that, in the next twenty years, the drone industry will directly employ over 100,000 people and will impact the economy in excess of 10 billion euros per year-which will mostly be associated with the service sector. ${ }^{41}$ There are evidently advantages to their use.

But, as Fox explained, (2017) whilst the potential to use drones is only now being realised, the wider (international) community is far from coordinated in the approach to regulate their use, let alone in defining what a drone actually is. ${ }^{42}$ While their increased use has been

\footnotetext{
${ }^{39}$ Grumman Hatches a Mallard, Popular Science, Nov. 1946, at 121, 122, https://books.google.com/books?id=_CADAAAAMBAJ\&lpg=PA121\&dq=Grumman $\% 20 H a t c h e s \% 20 a \% 20 \mathrm{Ma}$ llard\&pg=PA121\#v=onepage \&q\&f=false [https://perma.cc/6MW8-QC7H].

${ }^{40}$ Although this estimate fails therefore also to account for the drones being personally made or made by unregistered and unrecognised sources.

41 ec.europa.eu/growth/sectors/aeronautics/rpas_en (last updated Oct. 23, 2017) ec.europa.eu/growth/sectors/aeronautics_en - the Internal Market, Industry, Entrepreneurship and SMEs [Accessed July 2017].

42 As Fox (2017) explained:

There are two broad categories:

1. fixed wing; and

2. rotary wing.

Although they can come in a variety of shapes and sizes.

The below provides the commonly used words and abbreviations for drones;

- Drone (much favoured by the French, for example, see the French Directorate for Civil Aviation (DGAC)),

- $\quad$ RPA/S (Remotely Piloted Aircraft or Remotely Piloted Aircraft System) - used mostly by International and National Aviation Agencies

- $\quad$ UAS (Unmanned Aerial System) - still largely used by the US (and UK)
} 
Accepted 10 September 2018 (Journal - Technology in Society)

Accepted manuscript available online: 21-SEP-2018

https://doi.org/10.1016/j.techsoc.2018.09.006

identified and is clearly anticipated, the ability to coordinate data and to police this growing sector remains fragmented. In England and Wales, for example, rather than being proactive and ensuring that systems are in place to either use them in a policing role or to monitor their use from an enforcement perspective, there remains a variance of approaches by the police services.

Most light drones are of the rotary-wing type, with four, six or eight sets of rotors, with a common format being the quadcopter, a helicopter that is lifted and propelled by four rotors. The quadcopter is frequently used to carry a camera, which may have a wireless data link to the ground. This provides for real-time surveillance to be undertaken, at minimum cost, particularly when compared with a helicopter. That said, their capability and use is far more extensive than just this task; and, in actual fact, this association stands to have a negative connotation, as it derives direct linkage to military surveillance. Roossinck (2005) referred to just this notion when he stated that, "symbiosis implies cooperation as in mutualistic symbiosis or antagonism as in parasitic symbiosis."

\subsection{Tomorrow's technology..... today...}

The use of drones for criminal purposes is already occurring (Fox, 2017). Drones are operated autonomously ${ }^{43}$ and provide the means to act with anonymity - without a personal presence being required. Drones have been used to transport and smuggle drugs and phones across the country, across borders and, into prisons. And, this has already led to counterdrone work being developed. ${ }^{44}$ It remains a real concern to society and to the police that the

- UA (unmanned aircraft) cited within EU (proposed) legislation

- UAV (the Unmanned Aerial Vehicle) - mostly used as a general reference (alongside drone) by the general population.

- SUA/SUSA's: Small Unmanned Aircraft and Small Unmanned 'Surveillance' Aircraft (UK).

${ }^{43}$ In defining 'autonomously,' Villasenor added - that he meant, 'without a human in control.'

${ }^{44}$ UK Government update on drones: [Accessed 1 May, 2018]

https://www.gov.uk/government/news/major-investigation-smashes-nationwide-prison-drone-gang 
Accepted 10 September 2018 (Journal - Technology in Society)

Accepted manuscript available online: 21-SEP-2018

https://doi.org/10.1016/j.techsoc.2018.09.006

potential for criminal use (including terrorist attacks) is only just being realised. So, whilst

society may raise an eyebrow to the police use of drones, drones in the hands of criminals

and terrorists is a much more terrifying thought and prospect - which could easily become a

reality (Fox, 2017).

This said, the police are only too aware that they need to balance perception of their use with the risk of using or not using such technology.

One of the first forces to use drones in England and Wales was Essex Police; and, yet, despite the obvious success, not all of the current 43 police forces have chosen to embrace this technology. As of the end of June, 2018, 21 permissions had been granted by the CAA to the police in England and Wales. ${ }^{45}$

\subsubsection{Case Study 1: Essex Police ${ }^{46}$}

In March 2014 and June 2014 there were two murders in Colchester, Essex. The first was a murder of a vulnerable male - James Attfield; and the second, was the murder of a Saudi Arabian Student - Nahid Almanea.

\footnotetext{
${ }^{45}$ FOI request by author to the CAA wherein the following are identified as having this permission granted: Bedfordshire Police, Cambridgeshire And Hertfordshire Constabularies;

British Transport Police

Cheshire Constabulary Trading as Cheshire UAS

Derbyshire Constabulary

Devon, Cornwall And Dorset Police Durham Constabulary

Essex Police

Kent Police

Lincolnshire Police

Norfolk Constabulary

North Wales Police

North Yorkshire Police

Northamptonshire Police and Northamptonshire Fire and Rescue Service

P.C.C For Merseyside (Merseyside Police)

South Wales Police

South Yorkshire Police

West Midlands Police (2 different permissions)

West Yorkshire Police and West Yorkshire Police 13XT Division

Wiltshire Police

${ }^{46}$ The author would like to thank Essex Police (in particular Inspector Aaron Connolly) for their support in writing this paper and for the information shared with the writer.
} 
The subsequent investigation identified two murder scenes. Large and sprawling in nature, the scenes were subject to significant policing activity including search by police specialist search assets. The teams, managed by a Police Search Advisor (POLSA) rely heavily on mapping and accurate imagery to depict where has been searched, but, more, importantly, where has not been. On this occasion the POLSA required aerial imagery. ${ }^{47}$ However, the images obtained via NPAS were unusable and afforded no possibility to stitch the imagery together to form one effective document.

This led to the use of a drone being authorised by police commanders and the Essex drone project began.

A 6-month trial period commenced, providing a 24 hour on call capability. The remit was to concentrate on vulnerable people, crime scenes and collision scene imagery. Deployment of the Essex Drone also occurred into the neighbouring police areas. Suffolk Constabulary utilised the drone technology during this period, which necessitated the use of a drone, over two days, to fly $168,000 \mathrm{~m}^{2}$ over a cornfield. This was to assist in the search for a missing pensioner. The investigating officer's only alternative was to cause the destruction of the crop by either placing search officers into the field or by chemical use - which would mean the soil would be unusable for 2-years. This would have cost Suffolk Constabulary $£ 98,000$ excluding staffing costs. This case and other usage during the 6-months, highlighted to Essex commanders the benefit of small drones as flexible, reactive solutions, capable of producing results comparable to their NPAS counterparts but at a far less cost.

\footnotetext{
${ }^{47}$ It is of note that images, such as Google, are rarely up-to-date sufficient for a crime scene search.
} 
Accepted 10 September 2018 (Journal - Technology in Society)

Accepted manuscript available online: 21-SEP-2018

https://doi.org/10.1016/j.techsoc.2018.09.006

Essex Police were only to aware of the need to mitigate negative press. Twitter

@Epolicedrone saw positive interaction with the public and around this time the synopsis of the twitter account was changed from "Using technology to protect vulnerable people" to "Bringing technology to the forefront of policing." This was a clear attempt to dispel any myths around the use of drones with regards to spying on people, or the associated military use of drones in Iraq, Afghanistan and Syria.

There is no doubt that Essex police have been careful to manage their use of drones by keeping the public informed via social media and other news outlets - via positive news stories and regular updates. This approach totally appreciates that the functions and duties of the police, including what could be perceived as controversial technology, is 'dependent on public approval.' It is likewise essential to be accountable, transparent and legitimate as to the use of drones in police operations. This totally adheres to the Peelian Principle of seeking and preserving public favour.

In 2017 Essex Police made 108 flights using drones, and in the first two months of 2018 there had been 34 flights recorded. ${ }^{48}$

- $55 \%$ of flights in 2018 were thermal imagery flights; and,

- $\quad 67 \%$ of flights (in 2018) would have been flown by NPAS.

Essex police have clearly shown that by choosing and using technology, such as drones, lives can be saved and effective and efficient policing undertaken which is befitting to the $21 \mathrm{st}$ century and a vision for 2025 policing.

\subsection{Understanding the challenges}

${ }^{48}$ Up until $14^{\text {th }}$ Feb 2018. 
Accepted 10 September 2018 (Journal - Technology in Society)

Accepted manuscript available online: 21-SEP-2018

https://doi.org/10.1016/j.techsoc.2018.09.006

Understanding the challenges of using technology for policing purposes, which could be perceived as controversial or otherwise, is a key factor in managing the introduction and use of not only drones, but other developing technological areas - such as AI and advancing robotics. However, careful management and preparation is key also to realising opportunities that are brought about by their use in modern policing.

There can be little doubting the fact that drones, used by the public and for commercial purposes, will be a challenge which requires coordinated action of various national bodies. And of course, this extend to appreciating the use of such technology by the broader society, including the associated risks of usage or misuse. However, to fully understand and appreciate these challenges there needs to be in place suitable systems and processes. This necessitates appropriate overarching governance including the means and methods to coordinate and share information and data consistently.

Fox (2017) discussed the difficulties emanating from the lack of coordination across the European Union (EU) and the relationship of drones to the civil aviation arena. In the UK, the Civil Aviation Authority (CAA) has the remit as the specialist aviation regulator, which by enlarge remains subject to governance and oversight by the European Commission (EC) and in particular the ever-evolving European Aviation Safety Agency (EASA). ${ }^{49}$ EASA has amongst other tasks, to ensure the highest common level of safety protection for EU citizens, and to ensure that there is single regulatory and certification process among Member States (Fox, 2016). However, EASA acknowledges that whilst smaller drones are increasingly being used in the EU there remains a fragmented regulatory framework in place to monitor their

\footnotetext{
${ }^{49}$ Of course, Britain's withdrawal from the EU stands to have significant consequence to aviation (and therefore also potentially the developing area for drones, which EASA is also developing).

The Government, the UK Civil Aviation Authority and the entire aviation industry have clearly stated that their collective preference is to remain a member of the European Aviation Safety Agency (EASA).
} 
Accepted 10 September 2018 (Journal - Technology in Society)

Accepted manuscript available online: 21-SEP-2018

https://doi.org/10.1016/j.techsoc.2018.09.006

use. And, although national safety rules do exist, these rules differ with no consistent

approach being applied.

In 2015, the Riga Declaration, ${ }^{50}$ recognised the need to address this issue while equally acknowledging security risks and challenges emanating from their use. It was reiterated that "malicious use of drones cannot be entirely prevented by design or operational restrictions." It was therefore advocated within the Declaration, that "[i]t is the task of the national police and justice systems to address those risks." ${ }^{51}$ However, as Fox (2017) discusses this will be a difficult area to manage for both the CAA and the respective police services; and as yet, their respective roles are far from confirmed. ${ }^{52}$

\subsubsection{Case Study 2: Equipping the Police Service - Training and knowledge ${ }^{53}$}

In 2016, following a Freedom of Information request the College of Policing acknowledged that it did not hold or have information relating to using, trialling or considering use of drones in policing by each respective police service. Neither did it provide guidance to the police on how police officers should deal with allegations of suspected misuse of such devices used by members of the public. ${ }^{54}$

However, one of the remits and function of the College of Policing remains to achieve the workforce-related goals agreed by Police and Crime Commissioners and Chief Constables in

\footnotetext{
${ }^{50}$ Riga Declaration: On remotely piloted aircraft (drones) "Framing the future of aviation" Riga - 6 March 2015. ${ }^{51}$ Ibid.

52 Note: there is a follow-on paper to the 2017 publication, which addresses the legal and policy challenges of drones from a monitoring and enforcement perspective: (Fox, S. J. (20xx) - POLICING: MONITORING, INVESTIGATING and PROSECUTING: Drones) - anticipated publication date 2018.

${ }^{53}$ Ibid: This area is further discussed in the above publication.

${ }^{54}$ Freedom of Information request to the College of Policing, from unknown person(s). Identification reference marker: FOIA-2016-0038XXX dated, 25 April, 2016.
} 
Accepted 10 September 2018 (Journal - Technology in Society)

Accepted manuscript available online: 21-SEP-2018

https://doi.org/10.1016/j.techsoc.2018.09.006

the Policing Vision 2025. ${ }^{55}$ This vision is built on a shared goal to improve policing for the

public. Amongst the five reform priorities recognition was given to:

- The need to make '[s]pecialist capabilities, like armed policing, surveillance and major investigations' 'more affordable' and 'delivered through a network';

- Ensure '[p]olice officers will be trained and equipped to respond to the dramatic rise in criminals taking advantage of the internet...'

It was clearly stated that,

- 'The College of Policing will work with forces to give [the] workforce the skills and powers they need to meet these challenging requirements.....'

However, it is argued that in order to equip the police service to deal with societies challenges, it must be better coordinated and prepared, including in respect to training and knowledge in the technologies that exist and will become widely available and used. The use of the internet by criminals was arguably not sufficiently foreseen and certainly the means for policing it are now grossly insufficient. There are clearly lessons to be learnt in this regard in respect to being better prepared and ahead of the game. This includes from the perspective of the government in terms of offering support and ensuring that appropriate legislation exists for enforcement purposes.

\footnotetext{
${ }^{55}$ At their second joint conference, "police chiefs and police and crime commissioners launch [ed] a vision for policing in 2025 that makes far better use of digital technology, is integrated with other agencies to prevent crime and delivers effective services to provide best value for money for the public." https://news.npcc.police.uk/releases/police-chiefs-and-pccs-set-out-a-vision-for-policing-in-2025 16 November 2016. Accessible at: Policing Vision 2025
} 
Accepted 10 September 2018 (Journal - Technology in Society)

Accepted manuscript available online: 21-SEP-2018

https://doi.org/10.1016/j.techsoc.2018.09.006

The Association of Police and Crime Commissioners Chair (in 2016) Vera Baird

QC acknowledged that,

"People want a responsive service that is able to tackle the future challenges and embrace the future opportunities of policing. " Adding that the 2025 "Vision sets out how the service needs to use technology .... how it needs to attract and retain a confident and professional workforce and how much [the police] intend to work with other agencies to work together to ensure that people are kept safe." ${ }^{, 56}$

From the perspective of drones, this will clearly necessitate the police working closer together, including with other agencies, such as the CAA, in both respect to their use and of policing societies use of these devices.

Yet, in 2018, there is clear evidence that policing has not learnt from being prepared in terms of embracing technology and educating staff to respond to both the opportunities and challenges that drones present, as shown through the police service responses to a Freedom of Information request by the author (Table 1: Thames Valley Police and Table 2: Hampshire Constabulary). There remain inconsistencies across England and Wales, as to the approach of utilising drones operationally, as well as with regards to internal policies - including the recording of offences (Fox, 2018). Unlike Essex Police, neither Thames Valley Police or its close partner police service Hampshire Constabulary have specialist officers to fly drones and both have stated that drones have not been deployed for policing purposes. Whilst identifying that Thames Valley Police and Hampshire Constabulary have a long-standing

\footnotetext{
${ }^{56}$ See: The National Police Chiefs' Council website and specifically:

https://news.npcc.police.uk/releases/police-chiefs-and-pccs-set-out-a-vision-for-policing-in-2025
} 
Accepted 10 September 2018 (Journal - Technology in Society)

Accepted manuscript available online: 21-SEP-2018

https://doi.org/10.1016/j.techsoc.2018.09.006

relationship to work more closely to improve efficiencies and service to the public, neither

have chosen to embrace the technology that drones could arguably provide in this respect.

\begin{tabular}{|l|l|}
\hline \multicolumn{1}{|c|}{ Request by author } & \multicolumn{1}{|c|}{ Response by police service } \\
\hline $\begin{array}{l}\text { (1) What training (please specify nature and } \\
\text { training packages - i.e. in-class, Moodle }\end{array}$ & $\begin{array}{l}\text { (1) No specific information held. No } \\
\text { training packages specific to drones have } \\
\text { NCALT }{ }^{57} \text {, etc.,) on drones (including } \\
\text { legislation and offences) is provided to staff, } \\
\text { within }\end{array}$ \\
$\begin{array}{l}\text { (i) Contact Management - control room and } \\
\text { call handling staff; }\end{array}$ & \\
$\begin{array}{l}\text { (ii) And, to all operational police officers (I- } \\
\text { hub, Response, neighbour, CID, Special } \\
\text { Constables, etc). }\end{array}$ & \\
\hline $\begin{array}{l}\text { (2) Do you have specialist officers/staff for } \\
\text { drones in Thames Valley Police? }\end{array}$ & $\begin{array}{l}\text { (2) No information held. Thames Valley } \\
\text { Police do not have specialist officers or staff } \\
\text { for drones. }\end{array}$ \\
$\begin{array}{l}\text { (i) Please specify how many officers/staff } \\
\text { are trained and to what level? }\end{array}$ & \\
\hline $\begin{array}{l}\text { (3) Has Thames Valley Police - ever flown } \\
\text { a drone for policing purposes and if so the } \\
\text { nature, date/time of each event (in the } \\
\text { period - Jan. 2017 - to the current period). }\end{array}$ & $\begin{array}{l}\text { (3) No information held. Thames Valley } \\
\text { Police have not flown a drone for policing }\end{array}$ \\
\hline
\end{tabular}

TABLE 1: Thames Valley Police (May 2018)

\begin{tabular}{|l|l|}
\hline \multicolumn{1}{|c|}{ Request } & \multicolumn{1}{|c|}{ Response } \\
\hline $\begin{array}{l}\text { (1) What training (please specify nature and } \\
\text { training packages - i.e. in-class, Moodle } \\
\text { NCALT, etc.,) on drones (including } \\
\text { legislation and offences) is provided to staff, } \\
\text { within }\end{array}$ & been delivered. \\
(i) Contact Management - control room and \\
call handling staff; \\
$\begin{array}{l}\text { (ii) And, to all operational police officers (I- } \\
\text { hub, Response, neighbour, CID, Special } \\
\text { Constables, etc). }\end{array}$ \\
\hline
\end{tabular}

\footnotetext{
${ }^{57}$ NCALT - is an abbreviation of the Managed Learning Environment (MLE) used by the police and refers to National Centre for Applied Learning Technologies.
} 
(2) Do you have specialist officers/staff for drones in Thames Valley Police?

(i) Please specify how many officers/staff are trained and to what level?

(3) Has Thames Valley Police - ever flown a drone for policing purposes and if so the nature, date/time of each event (in the period - Jan. 2017 - to the current period).
(2) Not held as Hampshire Constabulary does not have specialist officer/staff for drones.

(3) Not held as Hampshire Constabulary has no drone deployments.

TABLE 2: Hampshire Constabulary (May, 2018)

\section{Conclusion}

The police are certainly no stranger to criticism and this includes their use of technology. But policing cannot live in the $19^{\text {th }}$ century and remain in the Peelian era. Regardless of public pressures, it must evolve and adapt. 'Survival of the fittest' is a phrase that originated from the Darwinian evolutionary theory. This does not mean, as applied to policing, that the police should be seen as supreme and dominant; however, it should be viewed that policing has to be strong and appropriate, so as to support a continually developing and evolving society.

In his theory of natural selection, Darwin suggested that organic evolution (the change of living things with time) was both biological and natural. And the same, it should be concluded, applies to the police - their development and their implementation of technology mirrors greater societies evolutional needs. Long after Darwin, biologists discovered that DNA changes as we evolve - in essence, it remains a natural phenomenon. There are few exceptions. Mankind is forever adapting due to this evolutionary mechanism, and the police, as a segment of society, will also need to. The choice ultimately remains as to whether policing follows suit, or, even ideally, leads in the new (fourth) technological revolution that 'we,' modern-society, stand on the cusp of. The alternative is that, what 'we' recognise as, the police, will end up dying off and/or being replaced if it does not move and develop so as to be appropriate to societies needs and policing in the $21^{\text {st }}$ century. 
Accepted 10 September 2018 (Journal - Technology in Society)

Accepted manuscript available online: 21-SEP-2018

https://doi.org/10.1016/j.techsoc.2018.09.006

In the same way, today's police cannot be held responsible and accountable for mis-failings and failing of their ancestors - fellow police officers that came before them. And the police should not be over-judgemental as to their acceptance within society, which potentially risks their own advancement.

Whilst there are thoughts to suggest that "[c]itizens have fallen out of love with democracy... "58 this cannot be deduced or concluded to be the same regarding the police, particularly in England and Wales.

Of course, the police, and their role of 'policing society', needs to be consensual but it should also not be curtailed by 'pandering to public opinion' ${ }^{59}$ - particularly with regards to the introduction and use of technology. There is no doubt that some technology - such as drones, needs to be carefully introduced and managed, not just in the policing arena but within the wider society. However, there also needs to be acceptance that the police and policing has evolved and that lessons have been learnt from past mistakes. There must also be more trust. Today, there is clear separation of the military and the role of the police. Gone are the days when Chief Constables and Commissioners directly entered from a military background; however, what should be welcomed and embraced is the legacy that passed to modern day policing, namely, that police remain 'principled ${ }^{60}$ ' - adhering to 'fairness, integrity, diligence and impartiality', 'according equal respect to all people' and 'upholding fundamental human rights.'

\footnotetext{
${ }^{58}$ As per section 1 - Introduction (Quote from Mounk).

${ }^{59}$ As within section 2.1.2. 'General Instructions' and public opinion.

${ }^{60}$ See Section 1: and the oath of allegiance which also constable swear to undertake by "truly serv[ing] the Queen in the office of constable" ... "with fairness, integrity, diligence and impartiality, upholding fundamental human rights and according equal respect to all people" (Police Reform Act 2002, Sct. 83). The police Code of Ethics further develops this into 9 principles: namely -

Accountability; Fairness; Honesty; Integrity; Leadership; Objectivity; Openness; Respect; Selflessness
} 
Accepted 10 September 2018 (Journal - Technology in Society)

Accepted manuscript available online: 21-SEP-2018

https://doi.org/10.1016/j.techsoc.2018.09.006

"Technology is a democratic instrument" (Nuth, 2008). New technologies remain an asset to both the police and those with criminal intentions. However, used intelligently and responsibly they can aid humanity. Society has a right to ask for accountability of the police and this extends to legitimacy and transparency - including the use of technology in policing, but this should also be tempered with societies acceptance that the police have as their primary objective the greater good - namely protecting society.

\section{References}

Bell, M (1994) Goethe's Naturalistic Anthropology: Man and Other Plants. Oxford University Press.

Bilz, K and Nadler, J. (2014) The Oxford Handbook of Behavioral Economics and the Law, Eyal Zamir \& Doron Teichman (Eds.)

Bohm, R and Haley, K. (2008) Introduction to Criminal Justice. McGraw-Hill Higher Education.

Bouwman, H., \& van de Wijngaert, L. (2009). Coppers context, and conjoints: A reassessment of TAM. Journal of Information Technology, 24, 186-201.

Cavanaugh, Kathleen and Hughes, Edel (2016) Rethinking what is necessary in a democratic society: militant democracy and the Turkish state. Human Rights Quarterly, 38 (3). pp. 623654. ISSN 0275-0392.

Colvin, C. A., \& Goh, A. (2005). Validation of the technology acceptance model for police. Journal of Criminal Justice, 33, 89-95.

Critchley, T. (1978) A History of Police in England and Wales (revised edition). London: Constable.

Darwin, C. On the Origin of Species by Means of Natural Selection (John Murray, London, 1859).

Foa, R. S. \& Mounk, Y (2016) The Democratic Disconnect. Journal of Democracy Volume 27, Number 3. pp. 5-17. 
Accepted 10 September 2018 (Journal - Technology in Society)

Accepted manuscript available online: 21-SEP-2018

https://doi.org/10.1016/j.techsoc.2018.09.006

Fox, S. J. (2014) The evolution of aviation: In times of war and peace-blood tears and salvation! International Journal of World Peace. Vol. XXXI No. 4 Dec. pp. 49-79.

Fox, S. J. (2016a) Flying challenges for the future: Aviation preparedness - in the face of cyber-terrorism. Journal of Transportation Security. First published online Sept. 2016. December 2016, Volume 9, Issue 3, pp 191-218.

Fox, S. J. (2016b) Legal Risk Management, Governance and Compliance. Globe Law and Business.

Fox, S. J. (2016c) BREXIT: A bolt from the blue! - Red sky in the morning? Issues in Aviation Law and Policy. Volume 16, No. 1. Autumn, 2016, pp 83-119.

Fox, S. J. (2017) THE RISE OF THE DRONES: Framework and Governance - Why risk it! 82 J. Air L. \& Com. 683-715

Fox, S. J. (2018) POLICING: MONITORING, INVESTIGATING and PROSECUTING: Drones (in press).

Grieve, J. D. G. (2015) Historical Perspective: British Policing and the Democratic Ideal. In by Paresh Wankhade, David Weir (eds.) Police Services Leadership and Management Perspectives. Page. 15-26. Springer.

Holdaway, S (1977) Changes in Urban Policing. British Journal of Sociology, 28/1: 119-37

Hu, P. J., Lin, C., \& Chen, H. (2003). Examining technology acceptance by individual law enforcement officers: An exploratory study. Intelligence and Security Informatics: Lecture. Notes in Computer Science, 2665, 209-222.

Jones, Trevor; Newburn, Tim and Smith, David - Policy Studies Institute, 1994. http://www.psi.org.uk/pdf/Democracy-and-policing.pdf [Accessed 17 March, 2018]

Joyce, P. (2011) Policing. Development and Contemporary Practice. Sage Publications.

Lindsay, Rachel., Jackson Thomas W. \& Cooke, Louise (2014) Empirical evaluation of a technology acceptance model for mobile policing. Police Practice and Research. 15:5, 419436.

Marx, G. (2001) Police and Democracy (From Policing, Security and Democracy: Theory and Practice) P. 35-45, 2001, Menachem Amir, Stanley Einstein, (eds). Ashgate.

Moffit, B. (2016) The Global Rise of Populism. Performance, Political Style, and Representation, Stanford University Press, Stanford.

Mounk, Yascha (2018) The People Vs Democracy: Why Our Freedom Is in Danger and How to Save It. Harvard University Press.

Newburn, Tim and Neyroud, Peter (2013) Dictionary of Policing. Routledge. 
Accepted 10 September 2018 (Journal - Technology in Society)

Accepted manuscript available online: 21-SEP-2018

https://doi.org/10.1016/j.techsoc.2018.09.006

Nunn, S. (2001) Police technology in cities: changes and challenges. Technology in Society 23 (2001) 11-27

Nuth, M. S. (2008) Crime and technology - Challenges or solutions?

Taking advantage of new technologies: For and against crime. Computer Law \& Security Report 24. Pp. 437-446

Padgett, Kathy G., Bales, William D. \& Blomberg, Thomas G. (2005) “Under Surveillance: An Empirical Test of Effectiveness and Consequences of Electronic Monitoring', Criminology \& Public Policy 5 (1): 61-91.

Orwell, G (2013) Nineteen Eighty-Four. Penguin Modern Classics. (First Published in 1949)

Peak, K (2009) Policing America: Challenges and Best Practices. Pearson/Prentis Hall.

Rawlings, P. (2002) Policing: A Short History. Cullompton, Devon: Willan Publishing.

Reiner, R. (2010) The Politics of the Police. Oxford University Press.

Reith, C. (1956) New Study of Police History. Oliver and Boyd, London.

Rossmo D. K. (2000) Geographic Profiling. Boca Raton, FL: CRC Press.

Roossinck (2005). "Symbiosis versus competition in plant virus evolution." Nature Reviews: Microbiology. Vol. 4, 917-924. Available online http://ebbteaching.unimuenster.de/courses/tut/storage/papers/roossinck- symbiosis-competition-plant-virusevolution-NRM-05.pdf: doi:10.1038/nrmi- cro1285 Published online [Accessed 01 May 2014].

Stutzer, Alois and Zehnder, Michael (2013) Is camera surveillance an effective measure of counterterrorism? Defence and Peace Economics, 24:1, 1-14.

Weatheritt, M (1986) Innovations in Policing. Croom Helm, London.

Winner, L. (1997) Technology today: utopia or dystopia? Social Research 64(3):999. 